\title{
Influence of recruitment and temperature on distribution of intertidal barnacles in the English Channel
}

\author{
R.J.H. Herbert ${ }^{*+\pi}$, A.J. Southward ${ }^{\ddagger}$, M. Sheader ${ }^{S}$ and S.J. Hawkins ${ }^{\ddagger}$
}

\begin{abstract}
*Medina Valley Centre, Dodnor Lane, Newport, Isle of Wight, PO30 5TE, UK. `School of Conservation Sciences, Bournemouth University, Talbot Campus, Fern Barrow, Poole, BH12 5BB, UK. ${ }^{\star}$ Marine Biological Association, The Laboratory, Citadel Hill, Plymouth, PL1 2PB, UK. SSchool of Ocean and Earth Science, University of Southampton, European Way, Southampton SOl4 3ZH, UK. ${ }^{\S}$ School of Biological Sciences, University of Plymouth, Drake Circus, Plymouth PL4 8AA, UK.

${ }^{\pi}$ Corresponding author, e-mail: rherbert@bmth.ac.uk
\end{abstract}

\begin{abstract}
Many warm-water (Lusitanian) species reach their limits in the central English Channel, failing to penetrate to the North Sea. We re-surveyed the eastern limits of the Lusitanian intertidal barnacles Chthamalus montagui and C. stellatus, from 1994 to 2004, a decade of exceptionally high sea temperatures, and found range extensions on both sides of the Channel compared to the 1950s and 1970s. Annual recruitment of Chthamalus on the English coast was monitored. There was a consistent gradient of low recruitment to the east of Portland Bill, with significant reductions coinciding with prominent headlands. Highest recruitment occurred during the warmest years. Cluster analysis showed a high degree of similarity of annual recruitment within coastal cells suggesting that local processes are also important. In 1999 we compared recruitment in the other common intertidal barnacles, the boreal Semibalanus balanoides and the non-native Elminius modestus, with Chthamalus spp. All species showed low recruitment between Selsey Bill and Portland Bill, suggesting habitat limitations and/or hydrographic mechanisms. Annual recruitment of Chthamalus at existing limits on the Isle of Wight was positively correlated with the number of days of westerly and south-westerly winds during the summer, coinciding with the pelagic larval phase. A 'pulse' of high Chthamalus recruitment on the Isle of Wight, measured during the summer of 2000, reversed population decline. Only a higher frequency of such pulses will maintain populations at existing limits and increase the rate of range extension towards the North Sea. Such extension will be limited by lack of hard substrata, but proliferation of coastal defence schemes in recent years is increasing suitable habitat for barnacles.
\end{abstract}

\section{INTRODUCTION}

The British Isles straddle a biogeographic boundary zone where southern (Lusitanian) and northern (Boreal) species overlap (Forbes, 1858; Crisp \& Southward, 1958; Lewis, 1964). Many rocky shore species have been surveyed in this region for 75 years, particularly along the English Channel where many Lusitanian species reach their northern geographic limits (Fischer-Piette, 1936; Moore \& Kitching, 1939; Crisp \& Southward, 1958; Crisp et al., 1981; Herbert et al., 2003; reviewed in Southward et al., 2004). These studies provide a baseline against which to judge the influence of global climate change.

There is an east-west gradient of shallow water species in the English Channel, with Lusitanian species prevalent in the western basin (west of the Isle of Wight) and coldwater species commoner in the eastern basin, reflecting the difference in temperature regimes (Crisp \& Southward, 1958). Between 1994 and 1996 average summer (JulySeptember) sea surface temperature (SST) in the western basin of the Channel varied between 15 and $17.5^{\circ} \mathrm{C}$, whereas in the eastern basin it was between 15.5 and $18^{\circ} \mathrm{C}$. In winter (December-February), average SST in the western basin was between 9 and $11^{\circ} \mathrm{C}$, whereas in the east it was 7.5$10^{\circ} \mathrm{C}$ (Climate Diagnostics Centre, 2000).
On the central south coast of England there are unusual tidal phenomena, with double high and low waters from east of Portland Bill to the Isle of Wight (Pingree \& Maddock, 1977; Barne et al., 1996). The tidal range at Swanage in Dorset is the smallest around the British Isles (2 m), restricting intertidal habitat, but this increases both to the east and west reaching $6 \mathrm{~m}$ at Dover and $4 \mathrm{~m}$ in Torbay. Tidal ranges increase away from the central Channel, reaching maxima of 8-9 $\mathrm{m}$ around Jersey and the Gulf of St Malo on the north coast of France. Weak $\left(<0.5 \mathrm{~m} \mathrm{~s}^{-1}\right)$ inshore tidal currents occur in Lyme Bay and off parts of the Sussex coast, yet turbulence and fast streams occur at major headlands such as St Alban's Head and The Needles, reaching between 1.75 and $3.0 \mathrm{~m} \mathrm{~s}^{-1}$ off Portland Bill during spring tides (Barne et al., 1996; Bruce \& Watson, 1998). While the residual tidal flow in the Channel is from west to east, either side of headlands, tidal eddies may occur, as at Portland Bill (Pingree \& Maddock, 1977). A major gyre reduces the easterly residual flow at the eastern end of the Isle of Wight between Bembridge and Selsey Bill during summer (Boxall \& Robinson, 1987; Guyard, 2000).

Further to extensive hydrographic studies the coast of England and Wales has been divided up in to sections or 'cells' which have largely independent sediment transport characteristics (Motyka \& Brampton, 1993), often differentiated 


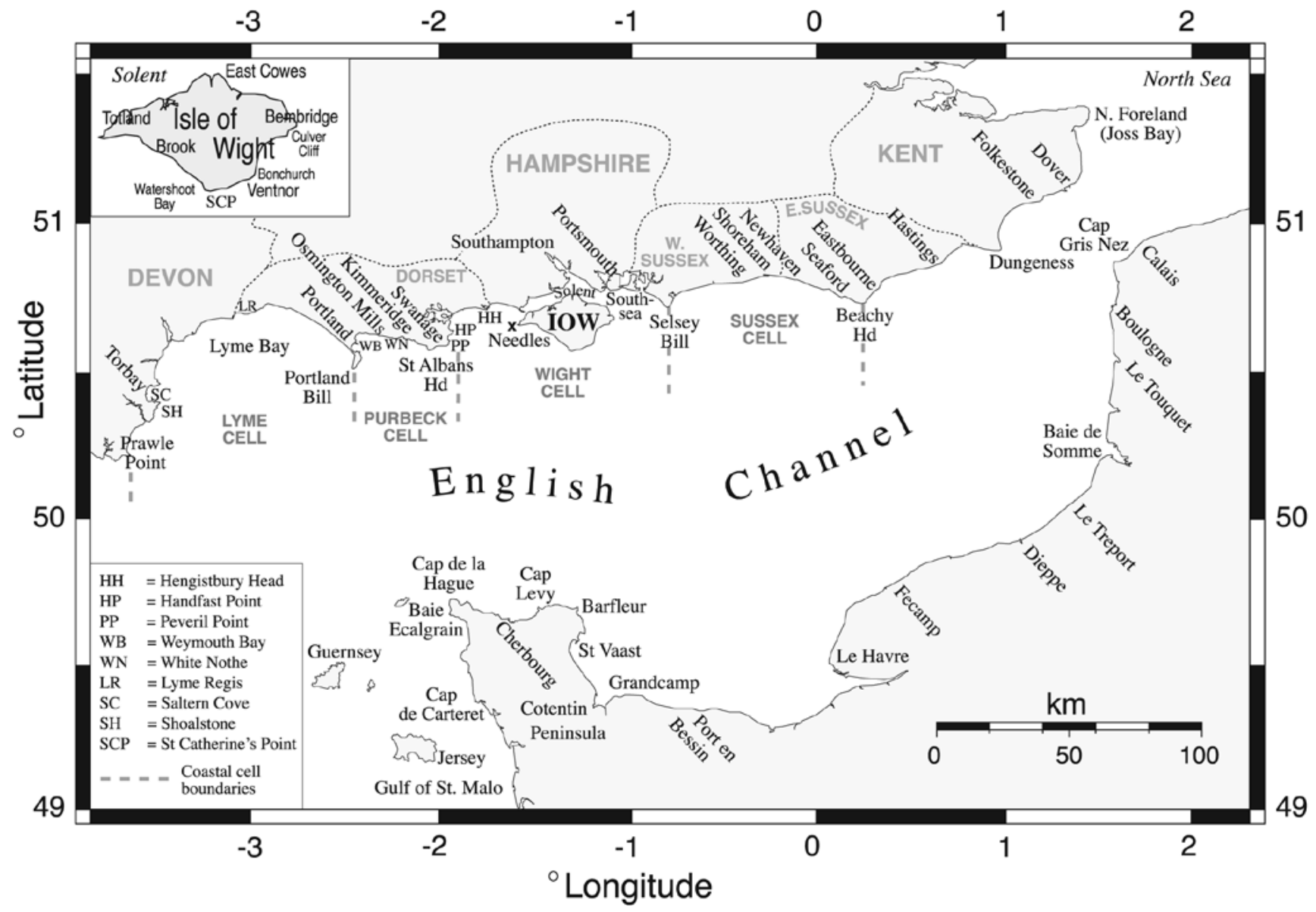

Figure 1. Central English Channel showing survey locations and boundaries of coastal process cells on the south coast of England that are referred to in the text.

by large headlands or promontories. Along the south coast of England there are three main cells, with many smaller embayments and sub-cells. It has been suggested that these cells may also be biologically different from their neighbours (Motyka \& Brampton, 1993).

Surveys in the Channel from 1950 to the late 1970s showed a major discontinuity in the abundance of the Lusitanian barnacle Chthamalus stellatus, now C. montagui Southward and C. stellatus Poli (Southward, 1976), and boreo-arctic Semibalanus balanoides (L.) along a line between the Isle of Wight and the Cotentin Peninsula (Figure 1). East of this region Chthamalus was virtually absent (Crisp \& Southward, 1958; Southward, 1964; Crisp et al., 1981) and Semibalanus much more abundant. It was suggested that the trends in distribution of barnacles and other intertidal animals were broadly related to temperature differences, with eastern limits determined not by lethal winter minimum temperatures, but through lower competitive ability compared to northern species, as the temperature falls (Crisp \& Southward, 1958; Connell, 1961). Additionally, other factors involved included barriers to larval dispersal and lack of habitat for settlement. In the eastern Channel, many shores consist of soft bedrock, including chalk, which are inimical to barnacle settlement and persistence of adults (Moore \& Kitching, 1939; Herbert \& Hawkins, 2006).

Time series on fluctuations in abundance of barnacles Chthamalus and S. balanoides provided evidence of climatic influence (Southward, 1991; Southward et al., 1995;
Herbert, 2001). During cooler periods, as in the 1960s and 1970s, Semibalanus predominated, whereas in warmer years such as the 1950s and the 1990s Chthamalus was more abundant. Annual counts near Plymouth in south-west England (Southward, 1991) showed the proportion of adult Chthamalus at mean tide level (MTL) and mean low water neap tide level (MLWN) was positively correlated with annual mean SST two years earlier, whereas S. balanoides was negatively correlated. Greater larval output and good settlement resulting from more broods during warmer years appear to be major factors causing an increase in the adult Chthamalus population. In contrast, in the single brooder Semibalanus the survival of juveniles is noticeably higher during cooler periods (Southward, 1991).

Our study had two main aims. First, to examine evidence for range extension of Chthamalus spp. during a period of increasing SST (Figure 2). Secondly, to examine the role of hydrographic barriers and habitat availability on recruitment, and hence in setting biogeographic boundaries in the region. To this end, levels of recruitment were measured and a simple model created to simulate larval output.

While coastal marine ecosystems are often considered highly open (Roughgarden et al., 1985; Gaines \& Bertness, 1992; Johnson, 2005), recent genetic investigations show a greater degree of small-scale differentiation of populations than might be expected (Duran et al., 2004). Our work contributes to the debate about connectivity in coastal 


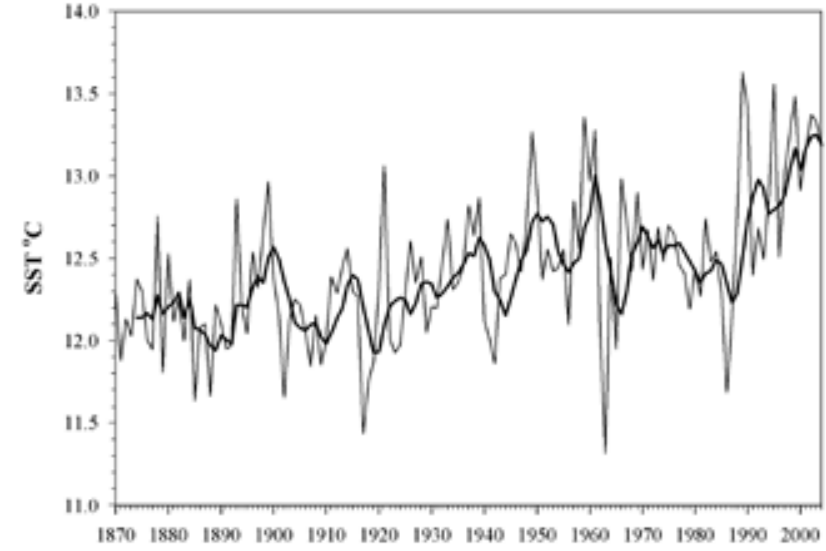

Figure 2. Sea surface temperature (SST) of central English Channel $\left(50-51^{\circ} \mathrm{N} 1-2^{\circ} \mathrm{W}\right)$ from $1870-2004$, shown as annual mean (thin line) and smoothed 5 year mean (thick line). Data extracted from the HadlSST1 data set (Raynor et al., 2003).

ecosystems and shows evidence for the existence of barriers that will interfere with the advance or retreat of species during periods of climate change (Gaines \& Gaylord, 2000; Lima et al., 2006).

\section{MATERIALS AND METHODS Initial survey}

Barnacle species distribution was assessed along the central south coast of England in the autumn of 1994 and repeated in subsequent years to 2004. In the autumn of 2001 and 2002, sites along the French coast between the Gulf of St Malo and Calais were also re-surveyed. Sites included those visited earlier (Crisp \& Southward, 1958; Crisp et al., 1981; A.J. Southward, unpublished database), thus extending the data set to over $50 \mathrm{y}$. The density of barnacle species Semibalanus balanoides (L.), Elminius modestus Darwin and Chthamalus spp. were recorded at three tidal levels using quadrats between $6 \mathrm{~cm}^{2}$ and $400 \mathrm{~cm}^{2}$ depending on abundance. Surveys were carried out on flat or gently sloping surfaces, except where these were not a characteristic feature of the shore. In such cases, counts were made on all accessible surfaces and aspects, including man-made substrata such as sea walls and groynes. If a species was not seen in the quadrats, a 30 minute search was carried out to check presence or otherwise. Species abundance was converted to a semi-quantitative scale (Table 1), consistent with Crisp \& Southward (1958). Species abundance's using this scale are shown in parentheses.

\section{Recruitment of Chthamalus along the central south coast of England}

In June 1994, prior to settlement of the species, six 400 $\mathrm{cm}^{2}$ clearances were created on the upper, middle and lower section of the limpet-barnacle zone (eulittoral zone (sensu Lewis, 1964)) at five sites between Torbay in Devon and Swanage in east Dorset. Clearances of $400 \mathrm{~cm}^{2}$ incorporated the range of microhabitat and surface topography thought to be important at low recruitment sites. For sites with low population densities, the same squares were re-scraped annually. At the end of the main Chthamalus settlement in
Table 1. Semi-quantitative scale to measure abundance of barnacles. After Crisp \& Southward (1958).

\begin{tabular}{ll}
\hline Frequency & Description \\
\hline $\begin{array}{l}\text { Abundant } \\
\text { Common }\end{array}$ & $\begin{array}{l}\text { More than } 1 \mathrm{per}^{2} \text {; rocks well covered } \\
0.1 \text { to } 1.0 \text { per } \mathrm{cm}^{2} ; \text { up to one third of rock space } \\
\text { covered }\end{array}$ \\
Frequent & $\begin{array}{l}0.01 \text { to } 0.1 \text { per } \mathrm{cm}^{2} \text {; individuals never more than } 10 \\
\mathrm{~cm} \text { apart }\end{array}$ \\
Occasional & $\begin{array}{l}0.0001 \text { to } 0.01 \text { per } \mathrm{cm}^{2} \text {; few within } 10 \mathrm{~cm} \text { of each } \\
\text { other }\end{array}$ \\
Rare & $\begin{array}{l}\text { Less than } 1 \text { per } \mathrm{m}^{2} ; \text { only a few found in } 30 \text { minutes } \\
\text { searching } \\
\text { None found }\end{array}$ \\
\hline
\end{tabular}

mid-October, the number of recruits was counted with the aid of a hand-lens. The two species of Chthamalus could not be separated immediately post-settlement, but careful examination of quadrats the following May (prior to reclearance), when the surviving recruits were larger, revealed only occasional $C$. stellatus throughout the whole period. Where densities of Chthamalus were very high, at least five sub-samples were taken. Each site was also checked in August during the middle of the settlement season to determine if there was any delay in settlement at the eastern localities, and whether a higher density of recruitment was evident that may not have survived until the end of the settlement season. To avoid damage to the small populations at the extreme eastern limits on the Isle of Wight, counts of new recruits were made within un-scraped areas of the shore at Hanover Point (Brook), Watershoot Bay and Bembridge where barnacle cover was generally less then $75 \%$. Ten quadrats $\left(400 \mathrm{~cm}^{2}\right)$ were placed within two patches at each of three tidal levels. Adult density of all barnacle species was also recorded. The recruitment surveys and adult census were repeated annually between 1994 and 2004. Meteorological information for the Isle of Wight was obtained from the Medina Valley Centre weather station (Medina Valley Centre, 2006) and from the Meteorological Office observer in Torquay, Devon.

\section{Recruitment of Semibalanus balanoides, Chthamalus spp. and Elminius modestus on vertical surfaces along the south coast of England in 1999}

The pattern of recruitment of other intertidal barnacle species was surveyed in neighbouring coastal cells east and west of the Isle of Wight. For consistency, it was decided to survey only vertical surfaces including walls, groynes and pilings as they are more common than natural platforms in the eastern cells. The coast from Prawle Point to Beachy Head was divided into four cells (Figure 1), broadly based on those cells or sub-cells differentiated largely by major headlands or hydrographic barriers (Motyka \& Brampton, 1993). These were named: 'Lyme' (Prawle Point to Portland Bill); 'Purbeck' (Portland Bill to Handfast Point near Swanage; 'Wight' (Handfast Point to Selsey Bill; and 'Sussex' (Selsey Bill to Beachy Head). The Purbeck Cell was further divided in to three sub-cells for the purpose of constructing a 


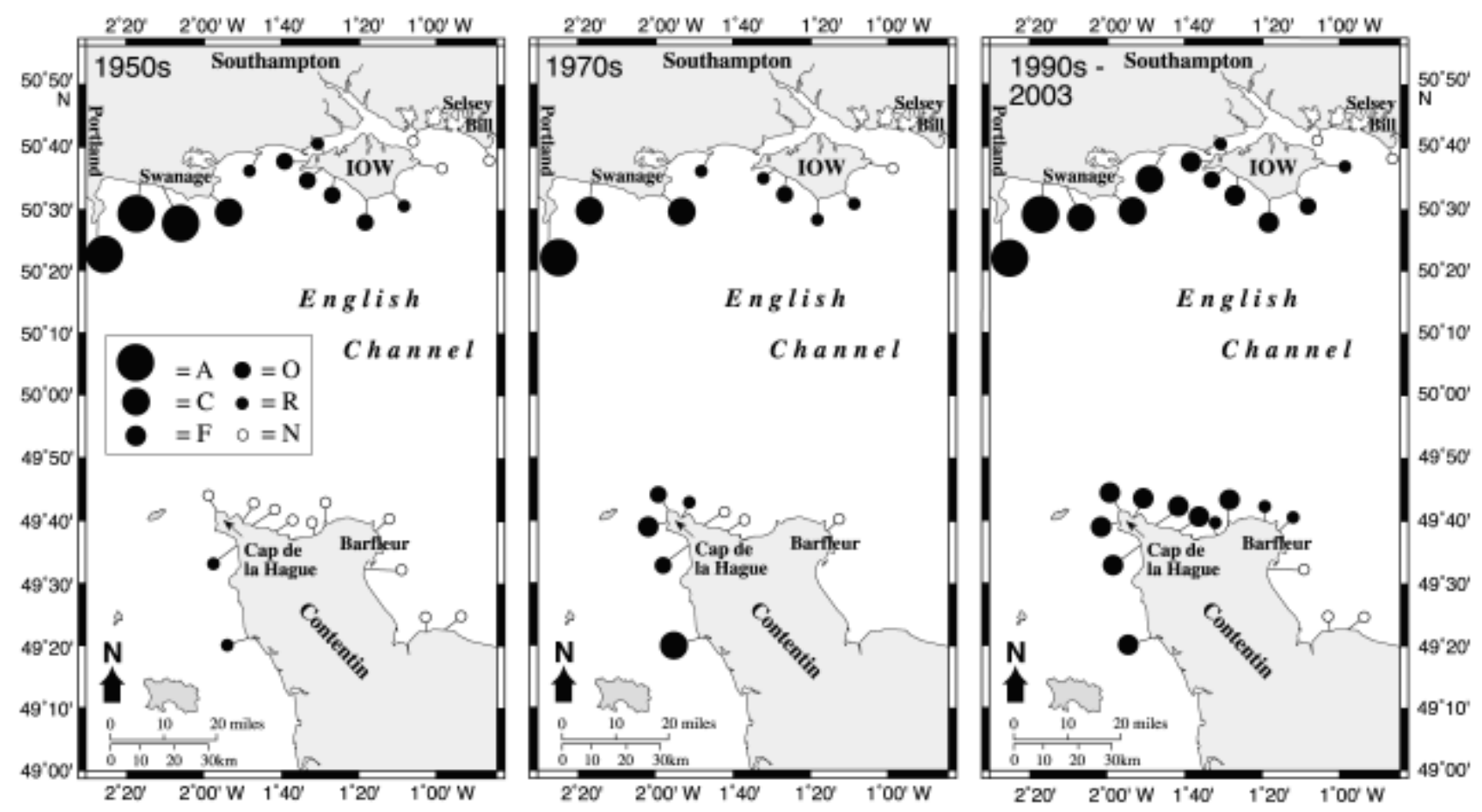

Figure 3. Mean shore abundance of total Chthamalus along the central English Channel. Data from the 1950s from Crisp \& Southward (1958) and the 1970s from Crisp et al., (1981) and A.J.S. unpublished. Prior to Southward (1976) all Chthamalus was recorded as C. stellatus. See Table 1 for Abundance scale parameters.

simulation model of recruitment: Purbeck a: Portland Bill to White Nothe; Purbeck b: White Nothe to St Albans Head; Purbeck c: St Albans Head to Handfast Point.

Within each cell, three representative shores were chosen. To determine within-shore variability, three random patches of ten $100 \mathrm{~cm}^{2}$ clearances were made at each of three tidal heights approximating to mean high water neap tide (MHWN), MTL and MLWN. Settlement of S. balanoides begins in March and early April (Crisp, 1959; Hawkins \& Hartnoll, 1982; Jenkins et al., 2000; Kent et al., 2003), so clearances were made well in advance during January and February. New clearances in different areas of each shore were made in May, prior to the settlement of Chthamalus and Elminius modestus. Each quadrat was scanned with a hand lens and sub-sampling used to calculate the mean density within each $100 \mathrm{~cm}^{2}$ clearance. A four-way analysis of variance (ANOVA) was carried out using GMAV 5 (Underwood et al., 1998) with factors Cell, Shores Tidal Height and Patch.

\section{Simulation model of barnacle larval output and recruitment within coastal cells}

The influence of coastal promontories and embayments in causing abrupt differences in recruitment regime was assessed by calculating recruitment as a proportion of estimated larval output from different localities along the south coast, up to the species eastern limits.

To determine the magnitude of Chthamalus and Semibalanus larval production within cells and sub-cells and hence recruitment as a percentage of larval output, the population density of the adult barnacle population had to be estimated. The area of intertidal rock along the south coast of England between Prawle Point and Beachy Head was calculated using the geographic information system (GIS) (MapInfo v. 5). Based on vertical species zonation illustrated by Lewis (1964) and a visual assessment along this moderately exposed coast, two-thirds of this area was considered to approximate to the limpet-barnacle zone. This zone was divided equally into the three areas 'upper' 'middle' and 'lower' and the adult population was calculated within each zone based on mean counts. An estimate of total larval output within cells was calculated for both taxa. For Chthamalus, a mean figure of 1000 eggs per brood with 2.6 broods per year was taken from Burrows et al. (1992). For Semibalanus, which has just a single brood, a mean figure of 2000 eggs per brood was taken from estimates by Barnes \& Barnes (1968) from shores in southern England. Recruitment was measured from counts as described above.

\section{RESULTS}

\section{Changes in distribution found by the re-surveys}

England

The two species of Chthamalus showed similar patterns of geographical distribution, with eastern limits on the Isle of Wight (Figures 3\&4). Both species showed eastward extensions and increased in abundance at earlier limits (Figure 3). Single individuals of C. montagui were found on limestone platforms near the lifeboat station at Bembridge in 1995 and 2001 (Figure 4), which is $8 \mathrm{~km}$ east of earlier limits at Bonchurch recorded in the late 1970s (Crisp et al., 1981). The eastern limits of $C$. stellatus were also found at Bembridge (Figure 4) approximately $26 \mathrm{~km}$ east of previous 

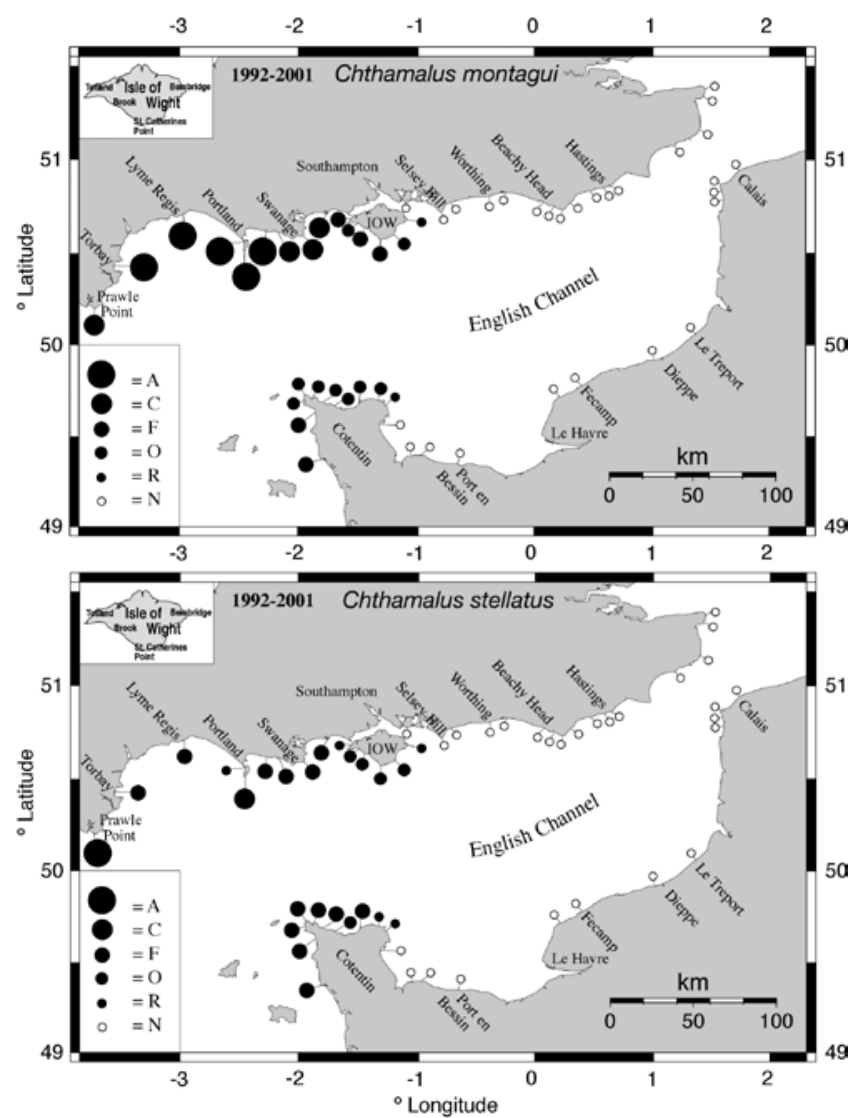

Figure 4. Distribution of Chthamalus montagui and C. stellatus east to existing limits in the central English Channel. Symbols along the south coast of England show the maximum mean-shore abundance observed during the period 1994-1999. On the French coast, symbols show the mean-shore abundance recorded during surveys in 2000 and 2001. See Table 1 for Abundance scale parameters.

records at Hanover Point (Brook) (Crisp et al., 1981). These small range extensions were confined to the Isle of Wight, and neither species was found on mainland shores to the east.

West of Portland, C. montagui was the most abundant barnacle between MTL and MHWN. On favourable substrata between MHW and MLWN mean densities of 4-6 per $\mathrm{cm}^{2}$ were recorded at sites in Lyme Bay where a maximum of 10.25 per $\mathrm{cm}^{2}$ was measured at MLWN at Lyme Regis. To the east of Portland Bill the density of adult C. montagui decreased along the Purbeck coast from 2-3 per $\mathrm{cm}^{2}$ at Osmington to $0.5-1$ per $\mathrm{cm}^{2}$ at Kimmeridge. Although still 'common' (Table 1) on the Long Groyne at Hengistbury Head, the density of $C$. montagui attenuates rapidly on the Isle of Wight. While a few individuals occur on the north-west coast of the island, the largest densities are on the southern shores at Hanover Point (Brook) and between St. Catherine's Point and Ventnor, where density can reach 0.05 per $\mathrm{cm}^{2}$ ('frequent') with a significant number of adjacent individuals. These shores may now be capable of forming an outlying breeding population as previous surveys found densities one or two orders of magnitude less (Figure 3). The species was found on a variety of rock types including the chalk boulders below Culver Cliff near Bembridge. Within the region Chthamalus stellatus was less abundant than C. montagui. As noted by Crisp et al., (1981),
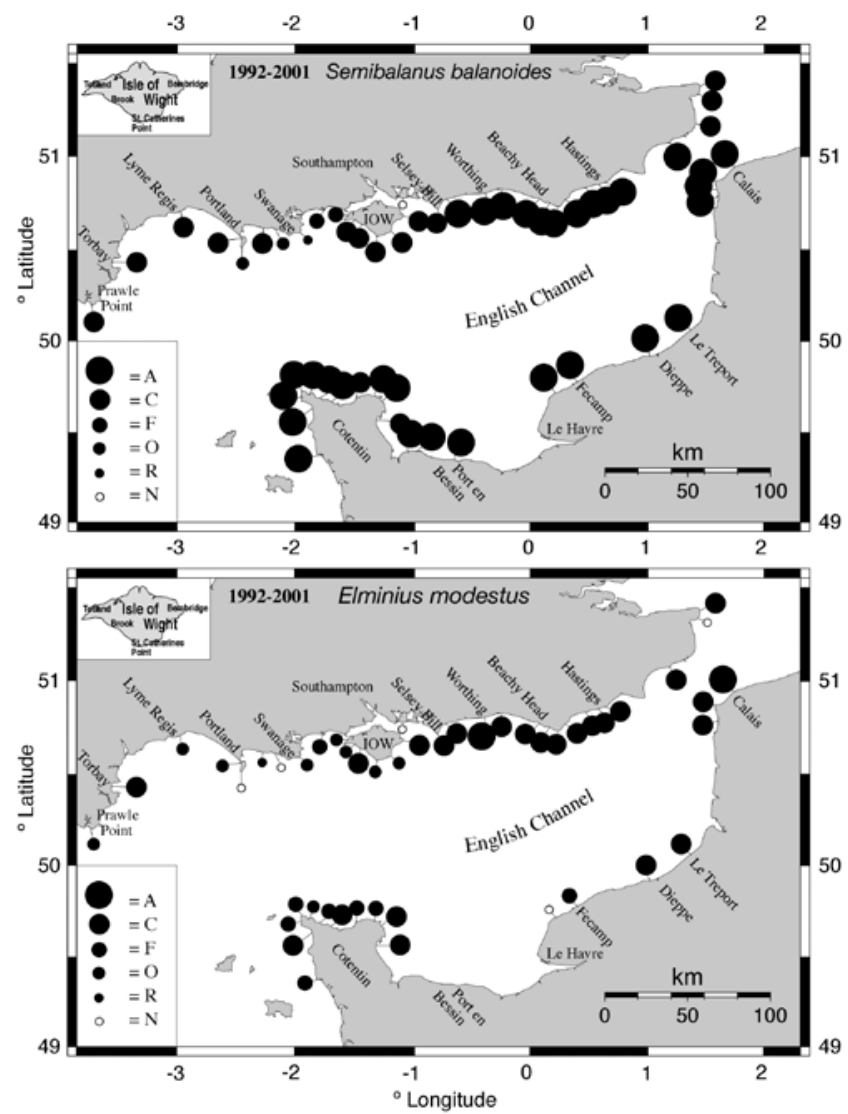

Figure 5. Distribution of Semibalanus balanoides and Elminius modestus in the central English Channel. Symbols along the south coast of England show the maximum mean-shore abundance observed during the period 1994-1999. On the French coast, symbols show the mean-shore abundance recorded during surveys in 2000 and 2001. See Table 1 for Abundance scale parameters.

in the western Channel C. stellatus is most abundant in the lower regions of the limpet-barnacle zone, but it was occasionally observed to extend above $C$. montagui near its eastern limits on the Isle of Wight. A similar phenomenon has been recorded at the limits of Chthamalus in north-east Scotland (Crisp, unpublished data). Maximum densities of 0.25 per $\mathrm{cm}^{2}$ were measured on the mid-shore at Portland Bill although the species still only accounted for less than $5 \%$ of the total Chthamalus recorded. Mean densities diminished east of Portland, yet maximum counts continued to be relatively high east along the Purbeck coast with 0.15 per $\mathrm{cm}^{2}$ recorded at Kimmeridge; densities accounting for over $12 \%$ of total Chthamalus on the lower shore were recorded there in 1994. On the Isle of Wight the species was generally classed as 'occasional' along its south coast, but because settlement is aggregated these populations should still be able to cross-fertilize and breed.

Semibalanus balanoides was ubiquitous although mean shore densities were higher east of the Isle of Wight. Densities of up to 11 per $\mathrm{cm}^{2}$ were measured on the sandstone rocks at Cow Gap near Eastbourne in Sussex and mean densities at MLWN were over 5 per $\mathrm{cm}^{2}$ (Figure 5 ). On the chalk at Seaford, mean shore densities of nearly 3.5 per $\mathrm{cm}^{2}$ were recorded and up to 12 per $\mathrm{cm}^{2}$ on the flints. Even at MHWN tide level the species was common with up to 2 per $\mathrm{cm}^{2}$ recorded at Shoreham. In contrast, on shores in 

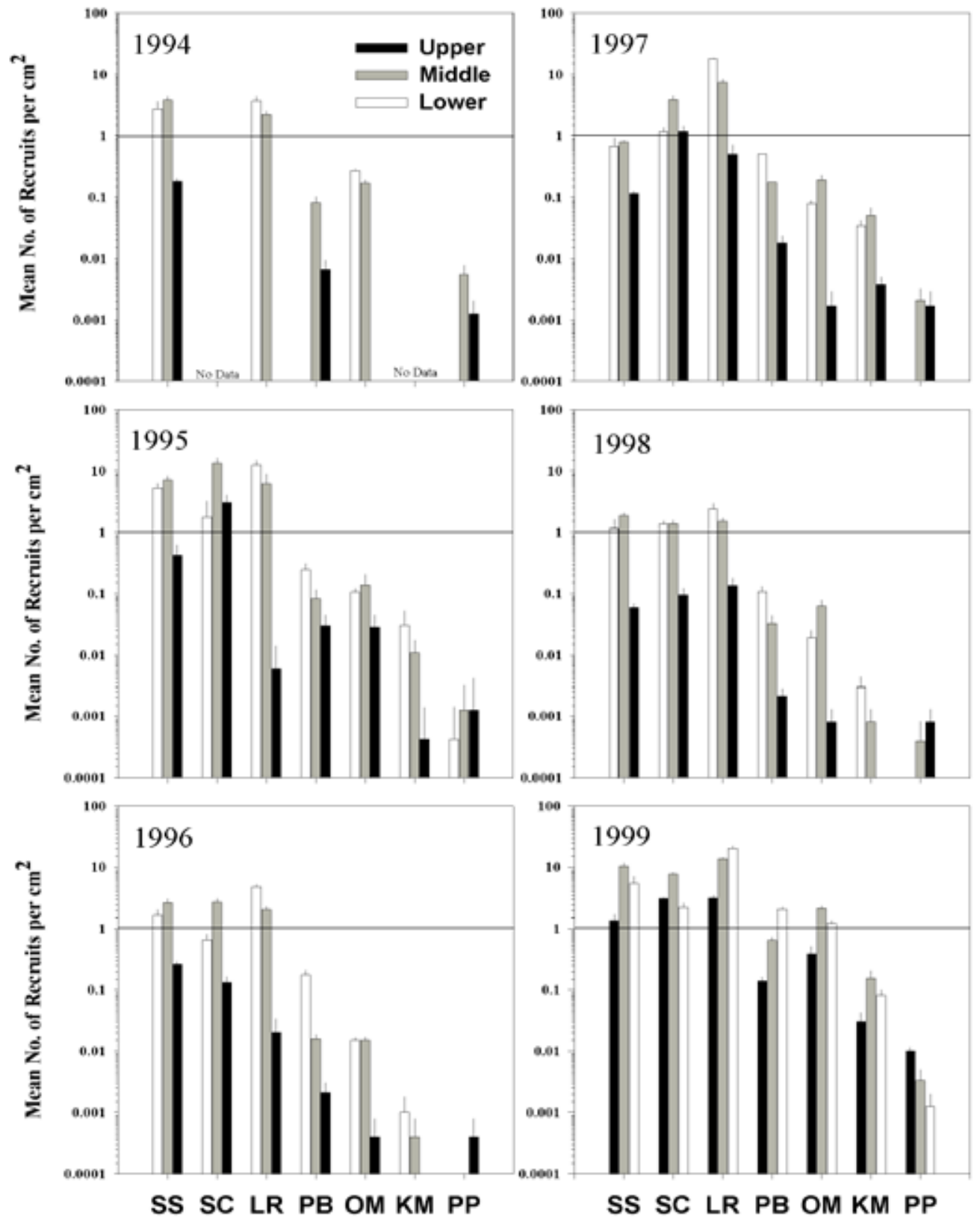

Figure 6. Mean Chthamalus recruitment at three tidal levels along the south coast of England from 1994 to 1999. Counts made in midautumn within cleared $400 \mathrm{~cm}^{2}$ quadrats ( $\mathrm{N}=6$ at each level). Note log scale. Error bars show + SE. Sites at Saltern Cove, Kimmeridge and lower shore of Portland Bill were not established until 1995. SS, Shoalstone; SC, Saltern Cove; LR, Lyme Regis; PB, Portland Bill; OM, Osmington Mills; KM, Kimmeridge; PP, Peveril Point.

Lyme Bay the species was hardly ever seen at this tidal level, where Chthamalus can cover nearly $100 \%$ of the rock. However at MLWN, maximum densities of 1 to 1.5 per $\mathrm{cm}^{2}$ were recorded for Semibalanus balanoides at Shoalstone and Saltern Cove and at Lyme Regis maxima of 2.5 per $\mathrm{cm}^{2}$ were measured at MTL.

Elminius modestus was also most common in the eastern Channel and particularly near estuaries (Figure 5). Highest densities were measured at Southsea where maxima of 4 per $\mathrm{cm}^{2}$ were recorded at MHWN. At Selsey Bill and at Worthing the species was 'common' or 'abundant'. At Shoalstone in Torbay, a maximum of 2.3 per $\mathrm{cm}^{2}$ was recorded at MLWN. East of Portland Bill, abundance was comparable with earlier surveys (Crisp, 1958; Crisp \& Southward, 1958), however, further west at Lyme Regis, where between 1948 and 1958 the species was absent, it is now 'occasional' and at Brixham it was 'abundant' when previously 'occasional'.

France

Both species of Chthamalus were found on all the northern shores of the Cotentin Peninsula (Figure 4). The record for Barfleur is approximately $50 \mathrm{~km}$ east of previous records in the 1970s, at just east of Cap de la Hague (Crisp et al., 1981). However, unpublished records of one of us (S.J.H.) made in 1983 show C. montagui and C. stellatus rare at Cap Levy and Barfleur. In 2001, C. stellatus was the most abundant of the two species on these exposed granite shores and 'frequent' to Cap Levy, where Chthamalus was not reported in the 1950s (Crisp \& Southward, 1958). At Baie d'Ecalgrain, immediately south of Cap de la Hague, mean-shore densities of C. stellatus 
Table 2. Three-way ANOVA of annual mean Chthamalus recruitment density (no. per $\mathrm{cm}^{2}$ ) within cleared patches at shores West and East of Portland Bill (known as West and East coastal cells). Data are untransformed. $\mathrm{P}$ values: *, $\mathrm{P}<0.05 ; * *, \mathrm{P}<0.01 ; * * *, \mathrm{P}<0.001$.

\begin{tabular}{|c|c|c|c|c|c|c|c|c|c|c|c|c|c|c|c|}
\hline \multirow{2}{*}{$\begin{array}{l}\text { Year } \\
\text { Source of } \\
\text { variation }\end{array}$} & \multicolumn{3}{|c|}{1995} & \multicolumn{3}{|c|}{1996} & \multicolumn{3}{|c|}{1997} & \multicolumn{3}{|c|}{1998} & \multicolumn{3}{|c|}{1999} \\
\hline & $\mathrm{df}$ & MS & $F$ & $\mathrm{df}$ & MS & $F$ & $\mathrm{df}$ & MS & $F$ & $\mathrm{df}$ & MS & $F$ & $\mathrm{df}$ & MS & $F$ \\
\hline Cell $=\mathrm{C}$ & 1 & 805.38 & $73.85^{* * *}$ & 1 & 74.38 & $25.06^{* * *}$ & 1 & 369.05 & 2.22 & 1 & 32.06 & $86.22^{* * * *}$ & 1 & 1530.6 & $11.12^{*}$ \\
\hline Shore $=\mathrm{S}(\mathrm{C})$ & 4 & 10.91 & $5.48 * * *$ & 4 & 2.97 & $9.34 * * *$ & 4 & 166.00 & $169.35^{* * *}$ & 4 & 0.37 & 1.32 & 4 & 137.6 & $13.35^{* * *}$ \\
\hline Height=H & 2 & 141.02 & 2.11 & 2 & 15.82 & 2.69 & 2 & 83.04 & 1.04 & 2 & 6.92 & 12.86 & 2 & 134.89 & 1.33 \\
\hline C X H & 2 & 138.00 & 2.07 & 2 & 15.68 & 2.67 & 2 & 80.85 & 1.02 & 2 & 6.68 & $12.41 * *$ & 2 & 97.20 & 0.96 \\
\hline H X S (G) & 8 & 66.81 & $33.6^{* * *}$ & 8 & 5.88 & $18.5^{* * *}$ & 8 & 79.61 & $81.22^{* * *}$ & 8 & 0.54 & $1.91 * *$ & 8 & 101.1 & $9.81 * * *$ \\
\hline Residual & 90 & 1.99 & & 90 & 0.32 & & 90 & 0.98 & & 90 & 0.28 & & 90 & 10.31 & \\
\hline \multicolumn{16}{|c|}{ Student-Newman-Kuels tests. ' $=$ ' denotes no significant differences. ${ }^{*}, P<0.05 ; * *, P<0.01}$. \\
\hline Cells & \multicolumn{3}{|c|}{$\mathrm{W}>\mathrm{E}$} & \multicolumn{3}{|c|}{$\mathrm{W}>\mathrm{E}$} & \multicolumn{3}{|c|}{$\mathrm{W}=\mathrm{E}$} & \multicolumn{3}{|c|}{$\mathrm{W}>\mathrm{E}$} & \multicolumn{3}{|c|}{$\mathrm{W}>\mathrm{E}$} \\
\hline Means & \multicolumn{3}{|c|}{$5.5>0.035 * *$} & \multicolumn{3}{|c|}{$1.66>0.004 * *$} & \multicolumn{3}{|c|}{$3.74=0.04$} & \multicolumn{3}{|c|}{$1.01>0.01 * *$} & \multicolumn{3}{|c|}{$7.98>0.45^{*}$} \\
\hline
\end{tabular}

were 0.06 per $\mathrm{cm}^{2}$ ('frequent') in 2000 compared to 0.02 per $\mathrm{cm}^{2}$ in 1979 (Crisp et al., 1981) but an order of magnitude greater at mean high water springs $\left(0.2\right.$ per $\left.\mathrm{cm}^{2}\right)$ than the earlier survey. Chthamalus montagui was 'frequent' here in 2000 compared to 'rare' in 1979 (Crisp et al., 1981). Shores on the north coast of the Cotentin Peninsula are now likely to have breeding populations of both Chthamalus species. The density of Semibalanus balanoides appeared to be relatively unchanged compared to earlier surveys (Crisp \& Southward, 1958). An increase of between one and two orders of magnitude was recorded in the abundance of $E$. modestus on the west side of Cotentin, where in 1954 it was 'rare' or 'occasional' (Crisp \& Southward, 1958).

\section{Recruitment of Chthamalus}

A consistent pattern was observed from west to east (Figure 6). Sites in Lyme Bay had greater recruitment of Chthamalus than those east of the major promontory at Portland Bill. In Lyme Bay, all three sites had mean recruitment densities of at least 1 per $\mathrm{cm}^{2}$, except for Shoalstone in 1997 (0.8 per $\mathrm{cm}^{2}$ ). The highest mean recruitment recorded in Lyme Bay was 20 per $\mathrm{cm}^{2}$ on the lower shore at Lyme Regis in 1999, when a maximum count of 27 per $\mathrm{cm}^{2}$ was recorded from one quadrat. There was an order of magnitude reduction in recruitment immediately east of Portland at Osmington Mills with densities exceeding 1 per $\mathrm{cm}^{2}$ in 1999 only. Densities were further reduced along the Purbeck coast to Peveril Point where the mean was never greater than 0.02 per $\mathrm{cm}^{2}$ (8 per $400 \mathrm{~cm}^{2}$ quadrat). At some shores there were also consistent differences in recruitment with tidal level. Shoalstone, Saltern Cove and Osmington Mills generally had higher recruitment on the middle shore, whereas at Lyme Regis, Portland Bill and Kimmeridge, densities were usually greater at lower tidal levels. The annual data between 1995 and 1999 were subject to three-way ANOVA (Table 2) with the main hypothesis being that recruitment was significantly different in the western cell (Lyme) compared to the eastern cell (Purbeck). To ensure a balanced design for this analysis, the highly wave-exposed shore at Portland Bill at the boundary between the cells was omitted. Factor 'Coastal Cell' was orthogonal and fixed; factor 'Shore' was nested in 'Coastal Cell' and was random; factor shore 'Height' was orthogonal and fixed. There were six replicates at each shore level sampled. The results indicate that there was a significant $(P<0.05)$ or highly significant $(P<0.001)$ difference in recruitment between coastal cells each year except 1997. In 1998 the difference was dependent on tidal height examined with differences being apparent at middle and lower levels. Apart from 1998, there were highly significant differences between shores; in each year the recruitment at a particular tidal height varied on different shores. Even in 1997 the mean recruitment in the western cell was three orders of magnitude greater than that in the eastern cell. Differences between shores in the eastern cell were not resolved by Student-Newman-Keuls (SNK) multicomparison procedure because of much larger variances, Table 2. A separate analysis was carried out on the eastern cell, which showed that the recruitment at Osmington Mills was greater than at both Kimmeridge and Peveril Point but there was again a significant Height $\mathrm{x}$ Shore interaction $(P<0.05)$. Observations in August did not show signs of mortality of newly-settled Chthamalus related to high summer rock temperatures. No cyprids or metamorphosing recruits were seen during shore visits at localities east of Portland Bill.

Greatest mean recruitment of Chthamalus occurred during the warmest year (1999) except at Saltern Cove, where recruitment was marginally greater in 1995. All shores, except for Shoalstone, had their lowest recruitment in the slightly cooler years of 1996 and 1998.

A Friedman test (Sokal \& Rohlf, 1997) on the rank-order of recruitment of Chthamalus at sites along the south coast (Table 3) showed that between 1995 and 1999 there was a high degree of concordance in the magnitude of Chthamalus recruitment $\left(\chi^{2}=22.8, \mathrm{~N}=8, \mathrm{df}=4, P<0.001\right)$. This implies that broad-scale factors, such as temperature and (or) wind direction, are likely to have an over-riding influence on annual recruitment variability.

To determine the level of similarity in Chthamalus recruitment variation between individual shores (and cells) a cluster analysis (Figure 7) using Bray-Curtis Similarity Indices (Bray \& Curtis, 1957) was undertaken. The annual 
Table 3. Rank order recruitment of Chthamalus at sites along a $140 \mathrm{~km}$ section of the south coast of England between 1995 and 1999. Sites listed from west to east. Rank 1 is lowest recruitment. SST is the maximum monthly mean recorded between Fuly and September for central English Channel (50-51 $\left.{ }^{\circ} \mathrm{N} 1-2^{\circ} \mathrm{W}\right)$ from HadISST1 data set (Raynor et al., 2003). Results of Friedman test applied with $H_{0}$ 'Years have same median recruitment' $\chi^{2}=22.8, \mathcal{N}=8, d f=4, \mathrm{P}<0.001 * * *$. Reject $H_{0}$ and accept $H_{1}$ that years differ.

$\begin{array}{lllll}1995 & 1996 & 1997 & 1998 & 1999\end{array}$

\begin{tabular}{lccccc}
\hline Shoalstone (Devon) & 4 & 3 & 1 & 2 & 5 \\
Saltern Cove (Devon) & 5 & 2 & 3 & 1 & 4 \\
Lyme Regis (Dorset) & 3 & 2 & 4 & 1 & 5 \\
Portland Bill (Dorset) & 3 & 2 & 4 & 1 & 5 \\
Osmington (Dorset) & 3 & 1 & 4 & 2 & 5 \\
Kimmeridge (Dorset) & 3 & 1 & 4 & 2 & 5 \\
Peveril Point (Dorset) & 3 & 1 & 4 & 2 & 5 \\
Hanover Point (Isle of Wight) & 4 & 1.5 & 1.5 & 3 & 5 \\
Median Rank & 3 & 1.75 & 4 & 2 & 5 \\
Max Mean SST ${ }^{\circ}$ C (July-Sept) & 17.92 & 16.70 & 17.42 & 17.30 & 17.97 \\
Rank SST & 4 & 1 & 3 & 2 & 5 \\
\hline
\end{tabular}

mean-shore recruitment, over three tidal levels, was calculated for eight shores within the study area over the period 1995-1999. The three main clusters show remarkable association with the location of known coastal process cells. Cluster 2 consists of all sites within 'Lyme' Cell, with the two sites in Torbay, Shoalstone and Saltern Cove, separated as a sub-grouping. The shores in Cluster 3 are all within 'Purbeck' Cell. The sub-group consisting of Osmington Mills and Portland Bill is unsurprising considering their close proximity. Cluster 1 consists of the two most eastern sites used in the analysis; Peveril Point on the Dorset coast and Hanover Point on the Isle of Wight.

\section{Recruitment on vertical surfaces along the south coast of England during 1999}

Recruitment of Semibalanus was highest along the Sussex coast (Figure 8A). Densities were greatest on the piles of Worthing Pier, where mean and maximum densities of 22 and 30 per $\mathrm{cm}^{2}$ respectively were measured at the upper shore level. There is a marked contrast between the high recruitment densities observed along the Sussex coast and those around the Isle of Wight and in east Dorset. In the Solent the recruitment density at East Cowes was, in comparison, relatively low with a mean of 1.6 per $\mathrm{cm}^{2}$ at one patch on the lower shore. At Kimmeridge, where $S$. balanoides recruitment on flat surfaces was almost zero, there were higher densities on vertical faces, with a mean of 0.2 per $\mathrm{cm}^{2}$ at one patch on the lower shore. In the east of Lyme Bay, relatively high mean-shore recruitment densities were observed at Saltern Cove and Lyme Regis of 8 and 11 per $\mathrm{cm}^{2}$ respectively. However, at each of these sites there was considerable variability both between tidal levels and within tidal level. The main conclusion from a four-way ANOVA, followed by SNK procedure, was that there is a significant difference in recruitment between coastal cells $(F=10.98$, $P<0.01)$ with the Sussex Cell having greater recruitment than

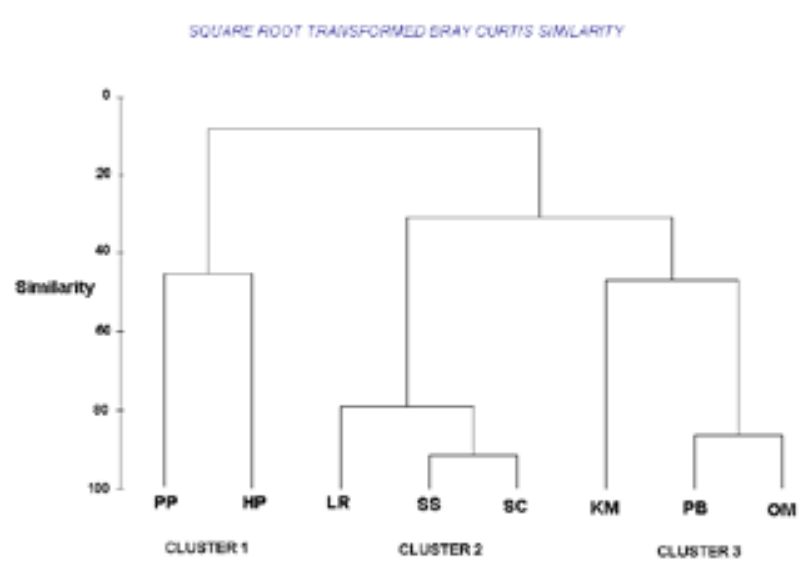

Figure 7. Dendrogram following cluster analysis of Bray-Curtis Similarity Indices using square-root transformed mean-shore recruitment of Chthamalus montagui at eight shores along the central south coast of England between 1995 and 1999. PP, Peveril Point; HP, Hanover Point; LR, Lyme Regis; SS, Shoalstone; SC, Saltern Cove; KM, Kimmeridge; PB Portland Bill; OM, Osmington Mills.

the three other cells further west $(P<0.01)$. The differences between shores were dependent on tidal height examined (Height $\times$ Shore interaction $P<0.01$ ).

Highest counts of Elminius were along the Sussex coast (Figure 8B) with 16 and 23 per $\mathrm{cm}^{2}$ being the mean and maximum recorded for a single patch at Selsey Bill. Yet ANOVA failed to resolve any differences between cells and differences between shores were dependent on tidal height examined; generally recruitment was greater at the lower level.

Chthamalus recruitment on vertical surfaces (Figure 8B) mirrored the pattern observed on shore platforms in Figure 6. Very high densities of recruits were measured in Lyme Bay with significant reductions east of Portland Bill, diminishing rapidly along the Purbeck coast. No recruitment of Chthamalus was recorded east of Watershoot Bay on the Isle of Wight. The highest mean patch density was 28 per $\mathrm{cm}^{2}$ on the lower shore at Lyme Regis. There was considerable variability between patches at each tidal level. The results of a four-way ANOVA and SNK test showed a significant difference between cells, with the 'Lyme' Cell having a significantly higher recruitment than the other cells further east $(F=13.12, P<0.01)$. A strong Height $\times$ Shore interaction indicated that differences between shores is dependent on tidal height examined.

Between 1994 and 2004 recruitment of Chthamalus measured at Hanover Point (Brook) on the south-west coast of the Isle of Wight (Figure 9) was either zero or extremely low. Yet there was a significant 'pulse' in 2000 that arrested adult population decline. A similar pulse was also measured at Watershoot Bay on the southern tip of the island. Over the decade, the summer (July-September) of 2000 had the second highest number of days when the wind was either from the west or south-west which may have facilitated larval transport from the larger populations further west along the Dorset coastline. In this area, between 1994 and 2004, annual recruitment was significantly correlated with the number of summer days the wind was from the west or south-west $(\mathrm{r}=0.67, P=0.03, \mathrm{~N}=10)$. The highest number of 

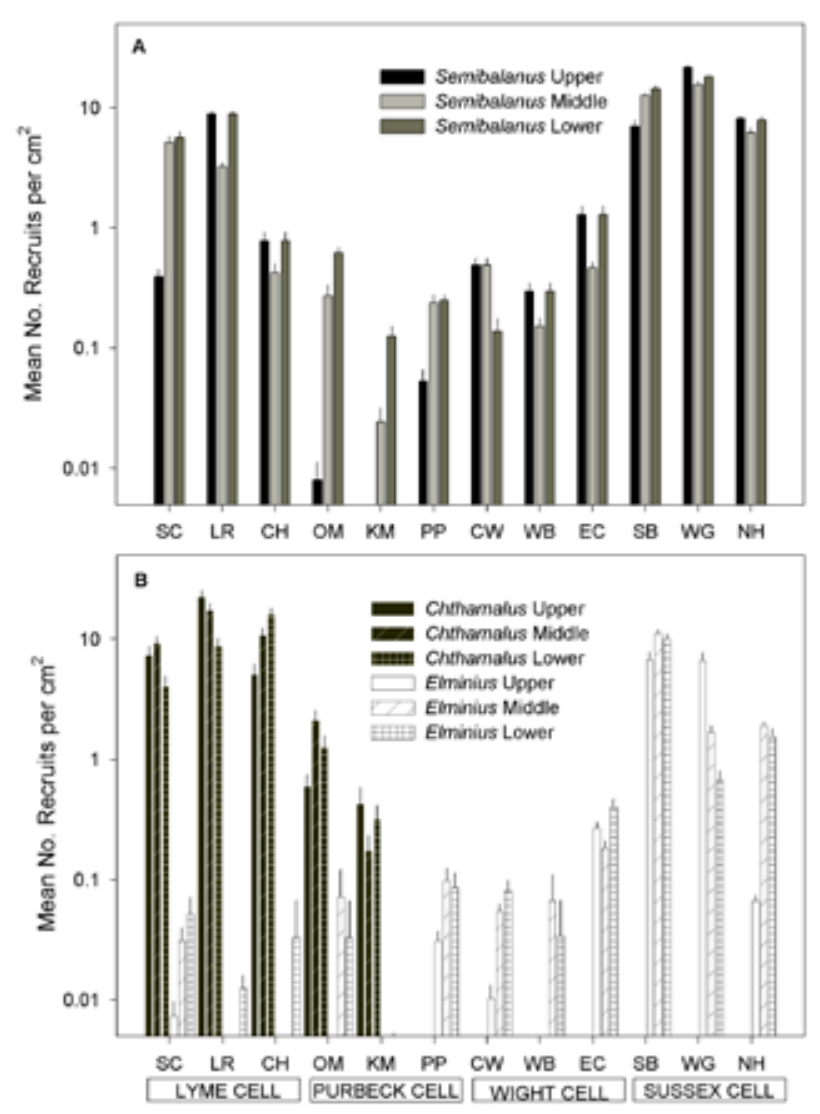

Figure 8. (A) Mean recruitment of Semibalanus balanoides and (B) Chthamalus and Elminius modestus at three tidal levels on shores along the central south coast of England in 1999. Note log scale. Most western site is Saltern Cove on left side of graph. Each bar represents mean of three patches of ten $100 \mathrm{~cm}^{2}$ quadrats $(\mathrm{N}=10)$. Error bars show +SE. SC, Saltern Cove; LR, Lyme Regis; CH, Chesil; OM, Osmington Mills; KM, Kimmeridge; PP, Peveril Point; CW, Colwell Bay; WB, Watershoot Bay; EC, East Cowes; SB, Selsey Bill; WG, Worthing; NH, Newhaven.

such days occurred in 2004 but there was also an unusual number of particularly strong winds that may have caused greater dispersal and been responsible for the relatively low recruitment measured, albeit the second highest since records began.

\section{DISCUSSION}

Subsequent to the previous survey of Chthamalus along this coast (Crisp et al., 1981), from the late 1980s there has been a succession of exceptionally warm summers and mild winters, with SST much higher than in the 1970s (Figure 2). Large range extensions of other southern species have been observed in the eastern Channel (Balanus perforatus, Herbert et al., 2003; Gibbula umbilicalis, Hiscock et al., 2004; R.J.H. Herbert, S.J. Hawkins and N. Miezkowska personal observation). In contrast eastern extensions of Chthamalus have been considerably smaller. The range extension of B. perforatus to East Sussex and Kent (Herbert et al., 2003; S.J.H. \& R.J.H.H., personal observation) may have been helped by its ability to occur subtidally, thus by-passing lack of solid surfaces in the intertidal. The rapid range extension of the trochid G. umbilicalis (Moschella et al., 2005) is less easy to explain considering their short pelagic life of 4-5

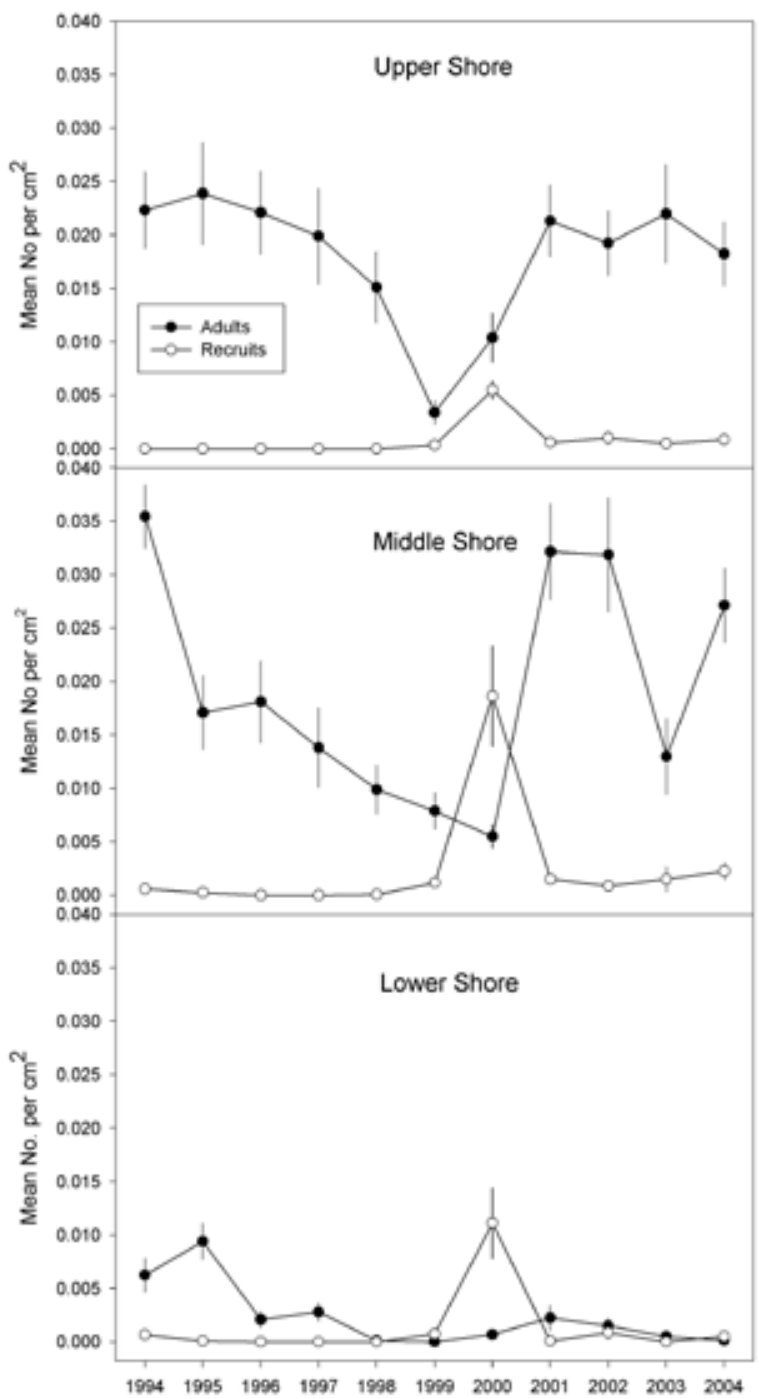

Figure 9. Annual recruitment and adult census of Chthamalus montagui at Hanover Point (Brook), Isle of Wight 1994-2004. Error bars show $\pm \mathrm{SE}$.

days (Fretter \& Graham, 1994). However G. umbilicalis, being mobile, may tolerate broken and boulder shores better than barnacles and thus able to bridge gaps in solid substrata. Other factors such as poor survival on the soft, friable chalk substrata (Herbert \& Hawkins, 2006) and competitive interactions with large populations of Semibalanus (Connell, 1961) may also be partially responsible for limiting the establishment of Chthamalus in the eastern Channel.

The ten-year time series and the broad-scale study of Chthamalus recruitment in 1999 all showed a steeply declining recruitment gradient of Chthamalus east of Portland Bill. Recruitment along the Purbeck and Isle of Wight coast was low for all species of intertidal barnacles including $S$. balanoides. Recruitment data for $S$. balanoides obtained in 1998 and 1999 by Kent et al. (2003) are consistent with this finding. Compared to sites further west, recruitment of Chthamalus measured on the Isle of Wight may have been slightly enhanced because quadrats were not cleared of adults and thus be more attractive to settlers. It is suggested that the reduction in intertidal barnacle recruitment in the 'Purbeck' and 'Wight' Cells is caused by physical and 
hydrographic barriers created by Portland Bill and Selsey Bill, which reduce both east and westward transport of larvae and subsequent settlement on the shore. Very low adult densities and considerably higher space availability observed on shores along the Purbeck and Isle of Wight coast support this view. Portland Bill was considered to be an important barrier to the westward dispersal and colonization of Elminius modestus (Crisp, 1958). Should S. balanoides retreat from the extreme south-west of England following higher temperatures, as occurred in the late 1940searly 1950s, then any subsequent recolonization from shores in the eastern Channel might be inhibited by hydrographic barriers associated with headlands.

A simple simulation model (see appendices) of Chthamalus recruitment within each coastal cell, incorporating estimates of habitat area, adult density and potential larval production showed that recruitment as a percentage of estimated larval production is reduced by between one and two orders of magnitude between Lyme Bay and the Purbeck coast. This could be indicative of greater larval retention within Lyme Bay and higher larval loss on the eastern side of Portland Bill on the Purbeck coast. Fewer recruits per adult reaching the shore could also be symptomatic of an Allee-effect (Allee, 1931; Kent et al., 2003) where because adult densities are so low, the minimum distance between individuals necessary for cross-fertilization is seldom reached. However in Chthamalus, this difficulty may be partly overcome by self-fertilization (Barnes \& Crisp, 1956). Between 1995 and 1998, investigations into the development of gonads and brooding of embryos in non-isolated individuals of $C$. montagui on the south coast of England found no evidence of impaired or delayed development at the extreme eastern limits of distribution (Herbert, 2001). A simulation model (see Appendices) for S. balanoides from data obtained in 1999 showed an order of magnitude reduction in percentage recruitment along the east Dorset coast and around the Isle of Wight compared to the more embayed coastline both to the east and west of these locations.

Consistent and significant reductions in the estimated percentage recruitment in localities of hydrographic dynamism and complexity would support the hypothesis that larval supply to the shore at these locations was the limiting factor. In spite of over-riding broad-scale influences, local meteorological and hydrographic processes are still important factors that can affect variation in recruitment and degree of spatial synchrony between cells.

During the study, highest Chthamalus recruitment occurred in the warmest summer of 1999 and lowest in the less warm years of 1996 and 1998. Moreover, there has been remarkable concordance in the level of recruitment at different locations along the whole coast. This suggests that in spite of the locally variable tidal regime, rock type and shoreline configuration, the magnitude of recruitment appears to be ultimately determined by an over-riding climatic or meteorological factor. Lewis (1991) suggested a correlation between Chthamalus recruitment and summer temperatures in Scotland, but the relatively poor regional synchrony also pointed to strong wind influences on this highly irregular coastline, as with Semibalanus (Hawkins \& Hartnoll, 1982). Comparison of spatial synchrony in the abundance of 40-plus intertidal species on rocky shores in north Scotland showed Semibalanus to have the most synchrony over a 20 year time series, which could be partly as a result of the comparatively long pelagic phase and hence dispersal period (Burrows et al., 2002). At Aberystwyth, on the Welsh coast, Kendall \& Bedford (1987) did not find any association between recruitment of $C$. montagui and summer air temperature. Hawkins \& Hartnoll (1982) found that settlement of $S$. balanoides around the Isle of Man was strongly correlated with onshore winds. Relatively calm seas with light onshore winds, often associated with warm summer anticyclonic conditions, are likely to provide good conditions for larval settlement of any intertidal species, and so it is difficult to separate wind effects from sea temperature. The greater frequency of easterly winds during the summer of 1995 may have been responsible for the particularly high recruitment of Chthamalus observed at Shoalstone and Saltern Cove within Torbay, which has an eastern aspect and may aid larval retention in other larger embayments along the coast. The small but significant 'pulse' of Chthamalus recruitment observed on Isle of Wight shores during 2000 is likely to have been caused by the favourable coincidence of several variables including a greater frequency of winds from the direction of larger populations and high sea temperature. Pulses of settlement may also have occurred on the French side of the Channel during the warm climate phase of the 1950s: a single Chthamalus montagui (recorded as C. stellatus at the time) was found $1 \mathrm{~km}$ west of Cap Gris Nez in May 1961 (Southward, 1964).

The probability of further eastward range extension of Chthamalus along the south coast of England, overcoming the barrier created by Selsey Bill and the lack of substrata to the east, is therefore dependent on a higher frequency of recruitment pulses on Purbeck and Isle of Wight shores which would increase the adult population and larval output at existing limits. New habitat created by sea defence works, such as those at Elmer (Moschella et al., 2005) may facilitate further eastward range extensions along the English coast, although no Chthamalus were seen on either natural or artificial substrata east of the Isle of Wight during surveys between 2004 and 2006 .

To summarize, there have been eastward range extensions of the warm water Chthamalus species on both sides of the Channel. These extensions have been greater on the south side of the Channel. On both north and south coasts the eastward extension of Chthamalus has been less than that shown by other southern species, indicating there is greater influence of hydrographic barriers and substratum.

We acknowledge support from NERC grant GR9/02390 (to S.J.H. and A.J.S.) and the MarClim Consortium (EN, EA, SNH, WWF, CCW, States of Jersey, Scottish Executive, defra, Crown Estates). S.J.H. was also supported by the EU 'Delos' project and by a NERC grant-in-aid funded MBA Fellowship.

\section{REFERENCES}

Allee, W.C., 1931. Animal aggregations: a study in general sociology. University of Chicago Press.

Barne, J.H., Robson, C.F., Kaznowska, S.S., Doody,J.P., Davidson, N.C., eds. 1996. Coasts and seas of the United Kingdom. Region 9: Southern England: Hayling Island to Lyme Regis. Peterborough: Joint Nature Conservation Committee. [Coastal Directories Series.] 
Barnes, H. \& Barnes, M., 1968. Egg numbers, metabolic efficiency of egg production and fecundity; local and regional variations in a number of common cirripedes. Fournal of Experimental Marine Biology and Ecology, 2, 135-153.

Barnes, H. \& Crisp, D.J., 1956. Evidence of self-fertilization in certain species of barnacles. Fournal of the Marine Biological Association of the United Kingdom, 35, 631-639.

Boxall, S.R. \& Robinson, L.S., 1987. Shallow sea dynamics from CZCS Imagery. Advances in Space Research, 7, 37-46.

Bray, J.R. \& Curtis, J.T., 1957. An ordination of upland forest communities of southern Wisconsin. Ecological Monographs, 27, $325-349$

Bruce, P. \& Watson, G., 1998. Tidal streams between Portland Bill and St. Albans Head. Lymington, Hampshire: Boldre Marine.

Burrows, M.T., Hawkins, S.J. \& Southward, A.J., 1992. A comparison of reproduction in co-occuring chthamalid barnacles Chthamalus stellatus (Poli.) and Chthamalus montagui Southward. Fournal of Experimental Marine Biology and Ecology, 160, 229-249.

Burrows, M.T., Moore, J.J. \& James, B., 2002. Spatial synchrony of population changes in rocky shore communities in Shetland. Marine Ecology Progress Series, 240, 39-48.

Climate Diagnostics Centre, 2000. www.cdc.noaa.gov

Connell, J.H., 1961. The influence of interspecific competition and other factors on the barnacle Chthamalus stellatus. Ecology, 42, 710-723.

Crisp, D.J., 1958. The spread of Elminius modestus Darwin in NorthWest Europe. Fournal of the Marine Biological Association of the United Kingdom, 37, 483-520.

Crisp, D.J., 1959. Factors influencing the time of breeding of Balanus balanoides. Oikos, 10, 275-289.

Crisp, D.J. \& Southward, A.J., 1958. The distribution of intertidal organisms along the coasts of the English Channel. Fournal of the Marine Biological Association of the United Kingdom, 37, 157-208.

Crisp, D.J., Southward, A.J. \& Southward, E.C., 1981. On the distribution of the intertidal barnacles Chthamalus stellatus, Chthamalus montagui and Euraphia depressa. Fournal of the Marine Biological Association of the United Kingdom, 61, 359-380.

Duran, S., Pascual, M., Estoup, A. \& Turon, X., 2004. Strong population structure in the marine sponge Crambe crambe (Poecilosclerida) as revealed by microsatellite markers. Molecular Ecology, 13, 511-522.

Fischer-Piette, E., 1936. Etudes sur la biogéographie intercotidale des deux rives de la Manche. Fournal of the Linnean Society (Zoology), 40, 181-272.

Forbes, E., 1858. The distribution of marine life, illustrated chiefly by fishes and molluscs and radiata. In A.K.Fohnston's Physical Atlas, pp. 99-101. Edinburgh: W \& A.K. Johnston.

Fretter, V. \& Graham, A., 1994. British Prosobranch Molluscs, 2nd edn. London: The Ray Society.

Gaines, S.D. \& Bertness, M.D., 1992. Dispersal of juveniles and variable recruitment in sessile marine species. Nature, London, 360, 579-580.

Gaines, S.D. \& Gaylord, B., 2000. Temperature or transport? Range limits in marine species mediated solely by flow. American Naturalist, 155, 769-789.

Guyard, P.H., 2000. Effects of oceanographic factors in the mesozooplanktonic communities of the east Solent and outer approaches. $\mathrm{PhD}$ thesis, University of Southampton, UK.

Hawkins, S.J. \& Hartnoll, R., 1982. Settlement patterns of Semibalanus balanoides (L.) in the Isle of Man (1977-1981). Fournal of Experimental Marine Biology and Ecology, 62, 271-283.

Herbert, R.J.H., 2001. Testing hypotheses related to changes in abundance and distribution of warm-temperate invertebrates on rocky shores along the south coast of England. $\mathrm{PhD}$ thesis, University of Southampton, UK.

Herbert, R.J.H. \& Hawkins, S.J., 2006. Effect of rock type on the recruitment and early mortality of the barnacle Chthamalus montagui. Journal of Experimental Marine Biology and Ecology, 334, 96-108.
Herbert, R.J.H., Hawkins, S.J., Sheader, M. \& Southward, A.J., 2003. Range extension and reproduction of the barnacle Balanus perforatus in the eastern English Channel. Fournal of the Marine Biological Association of the United Kingdom, 83, 73-82.

Hiscock, K., Southward, A., Tittley, I. \& Hawkins, S., 2004. Effects of changing temperature on benthic marine life in Britain and Ireland. Aquatic Conservation: Marine and Freshwater Ecosystems, 14, 333-362.

Jenkins. S.R. et al., 2000. Spatial and temporal variation in settlement and recruitment of the barnacle Semibalanus balanoides (L.) (Crustacea: Cirripedia) over a European scale. Fournal of Experimental Marine Biology and Ecology, 243, 209-225.

Johnson, M.P., 2005. Is there confusion over what is meant by 'open population'? Hydrobiologia, 544, 333-338.

Kendall, M.A. \& Bedford, M.L., 1987. Reproduction and recruitment of the barnacle Chthamalus montagui at Aberystwith (mid-Wales). Marine Ecology Progress Series, 38, 305-308.

Kent, A., Hawkins, S.J.H. \& Doncaster, C.P., 2003. Population consequences of mutual attraction between settling and adult barnacles. Fournal of Animal Ecology, 72, 941-952.

Lewis, J.R., 1964. The ecology of rocky shores. London: Hodder \& Staughton,

Lewis, J.R., 1991. Rationale methods and problems involved in the assessment and causes of recruitment fluctuations of some rocky shore species. In Space and Time Series data analysis in coastal benthic ecology (ed. B.F. Keegan). Brussels: CEC.

Lima, F.P., Queiroz, N., Ribeiro, P.A., Hawkins, S.J. \& Santos, A.M., 2006. Recent changes in the distribution of a marine gastropod Patella rustica Linnaeus 1758 and their relationship to unusual climatic events. Fournal of Biogeography, 33, 812-822.

Medina Valley Centre, 2006. Newport, Isle of Wight, UK. www. medinavalleycentre.org.uk

Moore, H.B. \& Kitching, J.A., 1939. The biology of Chthamalus stellatus (Poli). Fournal of the Marine Biological Association of the United Kingdom, 23, 521-541.

Moschella, P.S. et al., 2005. Low-crested coastal defence structures as artificial habitats for marine life. Using ecological criteria in design. Coastal Engineering, 52, 1053-1071.

Motyka, J.M. \& Brampton, A.H., 1993. Coastal Management - mapping of littoral cells. Report SR 328. Oxford: HR Wallingford.

Pingree, R.D. \& Maddock, L., 1977. Tidal eddies and coastal discharge. Fournal of the Marine Biological Association of the United Kingdom, 57, 869-875.

Rayner, N.A., Parker, D.E., Horton, E.B., Folland, C.K., Alexander, L.V., Rowell, D.P., Kent, E.C. \& Kaplan, A., 2003. Global analyses of sea surface temperature, sea ice, and night marine air temperature since the late nineteenth century. Fournal of Geophysical Research-Atmospheres, 108, (D14), 4407.

Roughgarden,J., Iwasa,Y. \& Baxter, C., 1985. Demographic theory for an open marine population with space-limited recruitment. Ecology, 66, 54-67.

Sokal, R.R. \& Rohlf, F.J., 1995. Biometry. The principles and practice of statistics in biological research. New York: W.H. Freeman \& Co.

Southward, A.J., 1964. The relationship between temperature and rhythmic cirral activity in some Cirripedia considered in connection with their geographic distribution. Helgoländer Wissenschaftliche Meersuntersuchungen, 10, 391-403.

Southward, A.J., 1976. On the taxonomic status and distribution of Chthamalus stellatus (Cirripedia) in the North-East Atlantic region: with a key to common intertidal barnacles of Britain. Fournal of the Marine Biological Association of the United Kingdom, 56, 1007-1028.

Southward, A.J., 1991. Forty years of changes in species composition and population density of barnacles on a rocky shore near Plymouth. Fournal of the Marine Biological Association of the United Kingdom, 71, 445-513. 
Southward, A.J., Hawkins, S.J. \& Burrows, M.T., 1995. Seventy years observations of changes in distribution and abundance of zooplankton and intertidal organisms in the western English Channel in relation to rising sea temperature. Fournal of Thermal Biology, 20, 127-155.

Southward, A.J. et al., 2004. Long term oceanographic and ecological research in the western English Channel. Advances in Marine Biology, 47, 1-105.
Underwood, A.J., Chapman, M.G. \& Sage, M., 1998. GMAV5 for Windowes. University of Sydney, Australia: Institute of Marine Ecology.

Submitted 5 December 2005. Accepted 12 November 2006. 


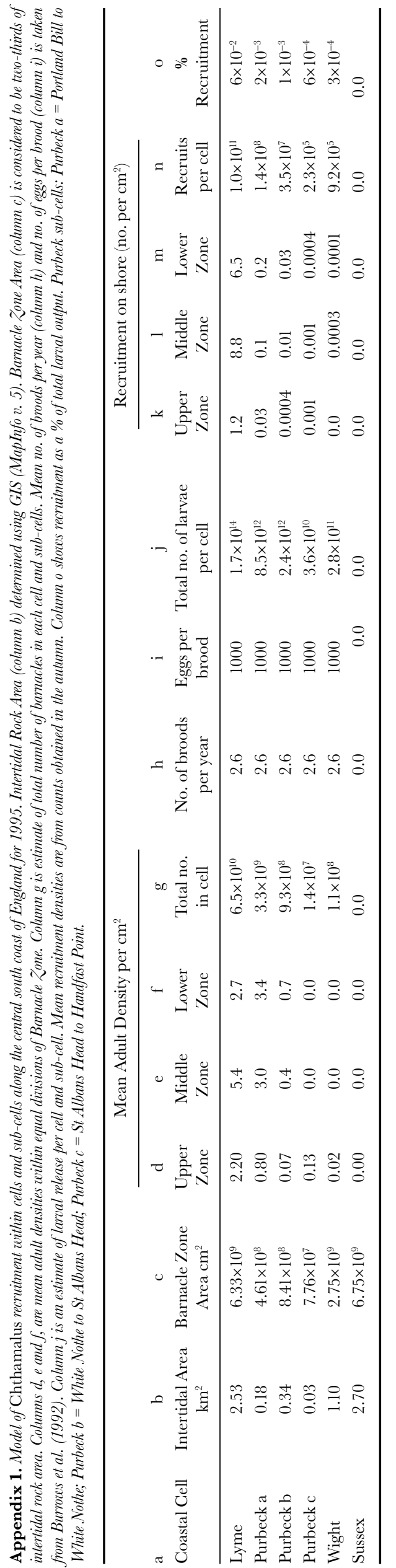

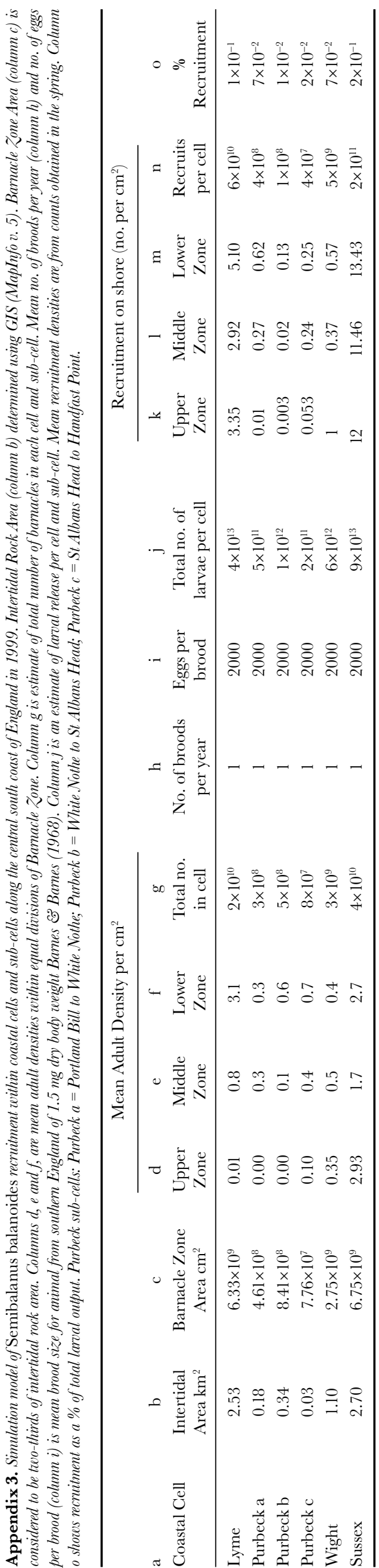


